\title{
Peranan Pemerintah Daerah Dalam Pemberdayaan Budaya Lokal (Studi tentang Program Pemberdayaan Pengrajin Batik Dalam Rangka Meningkatkan Komoditi Ekonomi di Desa Klampar Kecamatan Proppo Kabupaten Pamekasan-Madura)
}

\author{
Roro Merry Chornelia Wulandary ${ }^{1}$, Yuli Andy Gani ${ }^{1.2}$, Hermawan ${ }^{1.2}$ \\ Universitas Brawijaya \\ Jurusan IImu Administrasi Publik, Fakultas IImu Administrasi, Universitas Brawijaya
}

\begin{abstract}
Abstrak
Tujuan penelitian ini untuk mendiskripsikan dan menganalisis peranan pemerintah daerah dalam pemberdayaan budaya lokal. Metode penelitian kualitatif dengan teknik pengumpulan data melalui wawancara, dokumentasi dan observasi. Hasil penelitian menunjukkan bahwa peranan Dinas Perindustrian dan Perdagangan dalam pemberdayaan batik di Desa Klampar Kecamatan Proppo Kabupaten Pamekasan Madura telah dilaksanakan dan ada pula yang masih dalam perencanaan. Beberapa yang telah dilaksanakan adalah: 1). Permodalan melalui pinjaman Bank Perkreditan Rakyat (BPR); 2). Pelatihan membatik dan manajemen pemasaran; 3).Pemunculan nuansa batik dalam setiap agenda acara; 4). Mengikuti dalam berbagai agenda; 5). Membentuk paguyuban pengrajin batik; 6). Pembuatan sentra batik; 7). Mencari popularitas batik Pamekasan. Peranan pengrajin batik dan pengusaha batik antara lain: 1). Berasal dari sejarah batik yang masuk ke Desa Klampar; 2). Pemenuhan alat dan bahan; 3). Proses pembuatan batik di Desa Klampar; 4). Proses mempertahankan motif batik; 5).Proses pemasaran batik. Perencanaan yang kurang maksimal adalah: 1). Sumber daya manusia yang terlibat dalam usaha industri kecil masih rendah; 2). Proses daya saing pasar yang masih kurang; 3). Kualitas yang masih kalah saing dengan batik Pekalongan dan Jogyakarta. Faktor pendukung peranan Disperindag adalah: 1). Pembenahan sumber Daya Manusia dengan cara melatih pengrajin batik; 2). Pasar 17 agustus sebagai pasar batik Pamekasan diharapkan bisa menjadi lebih efektif untuk para pengusaha batik; 3). Motif batik pamekasan ini berbeda dengan motif-motif batik di daerah lain.
\end{abstract}

Kata Kunci: Budaya Lokal, Peranan Pemerintah Daerah, Pemberdayaan

\section{Abstract}

The purpose of this research to describe and analyze The Role of Local Government in Local Culture Empowerment. Qualitative research methods with techniques of data collection through interviews, documentation and observation. Research result shows that the role of National Department of Industry and Commerce in Batik empowerment at Klampar Village Proppo District Pamekasan Regency Madura had been conducted and the remaining still in planning progress. Some thing has been implemented: 1) Financing through the loan from BPR (Bank Perkreditan Rakyat); 2) Batik training and marketing management; 3) The emerging of Batik nuance in each event; 4) Following many agendas; 5) Creating organization or community of Batik craftsman; 6) Creating Batik center; 7) Looking popularity of Pamekasan Batik. The role of Batik craftsman and bussinessman such as: 1) Comes from Batik history that enter to Klampar Village; 2) Fulfillment of tool and material; 3) Process of Batik making in Klampar Village; 4) Process to keep Batik motive; 5) Process of Batik marketing. Planning is less than the maximum by: 1) Human resource that included in the small industry still low; 2) Less process of market competitiveness; 3) Quality that still lost competitiveness with Pekalongan and Jogjakarta Batik. Factor of National Department of Industry and Commerce are: 1) Settling Human Resources by training the batik craftsmen; 2) 17th August Market as Batik market Pamekasan expected that it can be more effective; 3) This Pamekasan Batik motive is different with Batik motive in the other area.

Keywords: The role of Local Government, Empowerment, Local Culture

\footnotetext{
Alamat korespondensi:

Roro Merry Chornelia Wulandary

Email : merrychornelia@yahoo.co.id

Alamat : Jurusan Ilmu Administrasi Publik, Program Pascasarjana Fakultas IImu Administrasi, UB
} 


\section{PENDAHULUAN}

Pada dunia yang semakin mengglobal ini rasanya sulit bagi suatu budaya untuk berdiri sendiri tanpa dipengaruhi budaya lain. Kemajuan teknologi ikut berperan dalam mengubah budaya yang terus mengglobal. Banyak alat yang digunakan sehari-hari dibuat dibeberapa tempat sebelum menjadi produk yang kita gunakan. Dalam waktu yang tidak lama lagi dapat diprediksi bahwa tidak akan ada lagi budaya yang murni budaya setempat. Hal-hal yang berpengaruh besar pada terbentuknya budaya global tersebut antara lain penggunaan radio, televisi, film, video, internet yang dapat menyebarkan suatu berita sampai ke seluruh pelosok dunia dengan cepat [4].

Menurut koentjaraningrat di dalam bukunya yang berjudul kebudayaan mentalitas dan pembangunan bahwa kebudayaan itu mempunyai paling sedikit tiga wujud, yaitu: 1). wujud kebudayaan sebagai suatu kompleks dari ide-ide, gagasan, nilainilai, norma-norma, peraturan dan sebagainya; 2). Wujud kebudayaan sebagai suatu kompleks aktivitas kelakuan berpola dari manusia dalam masyarakat; 3). Wujud kebudayaan sebagai benda-benda hasil karya manusia. Maka, hal inilah yang bisa membentuk mentalitas dan pembangunan kebudayaan yang ada di Indonesia sehingga budaya yang ada tetap sesuai dengan aslinya [3].

Isi dari jurnal berdasarkan tema, Pemerintah dan budaya (21) adalah: 1). sentral peran budaya dalam masyarakat serta Legitimasi peran budaya; 2). Kualitas pembangunan daerah tergantung pada jalinan kebijakan budaya dan masyarakat lainnya; 3). Pemerintah lokal: tanggung jawab bersama warga, masyarakat sipil dan pemerintah; 4).Peningkatan mekanisme penilaian dalam budaya (sistem indikator budaya); 5).Pentingnya jaringan dan kerjasama internasional; 6). Partisipasi pemerintah daerah dalam kebijakan budaya nasional dan program. Dari 6 hal diatas sudah jelas bahwa dibutuhkan sinergitas antara pemerintah dengan budaya untuk mewujudkan gendaagenda budaya di Indonesia. Di dalam cultural planning guidelines for local Goverment dinyatakan bahwa perencanaan budaya bertujuan untuk memberikan kesempatan bagi semua individu dan kelompok masyarakat untuk menjadi termasuk dalam kaya dan kehidupan budaya negara. Dewan lokal 'peran utama dalam memberikan kontribusi bagi kesejahteraan masyarakat lokal berarti bahwa mereka juga ditempatkan untuk mendukung lembaga-lembaga budaya dan untuk mendorong partsispasi inklusif dalam ekspresi budaya di tingkat lokal.

Dalam jurnal Pemerintah dan budaya memberikan kesempatan bagi setiap kota untuk membuat visi jangka panjang budaya sebagai pilar dasar dalam perkembangannya. Dokumen "anjuran atas pelaksanaan agenda 21 budaya lokal". Menarik konsep-konsep umum dan pertimbangan, dan menyarankan empat alat khusus (21) adalah: 1). Strategi kebudayaan lokal; 2). Piagam hak-hak budaya dan tanggung jawab; 3). Budaya dewan; 4).Pengaruh/ dampak budaya. 4 hal inilah yang akan menjadi pertimbangan dalam hal proses pelaksanaan agenda 21 budaya lokal. Keempat hal tersebut dinyatakan penting untuk mencapai arah gerak demi perkembangan budaya lokal yang ada pada.

Dengan adanya kebudayaan-kebudayaan ini maka harapannya dapat meningkatkan kesejahteraan sosial masyarakat. Istilah kesejarhteraan sosial bukanlah hal baru, baik dalam wacana global maupun nasional. Persatuan Bangsa-Bangsa (PBB), misalnya telah lama mengatur maslah ini sebagai salah satu bidang kegiatan masyarakat internasional. PBB memberi batasan kesejahteraan sosial sebagai kegiatan-kegiatan yang terorganisasi yang bertujuan untuk membantu individu atau masyarakat guna memenuhi kebutuhan-kebutuhan dasarnya dan masyarakat guna memenuhi kebutuhan-kebutuhan dasarnya dan meningkatkan kesejahteraan selaras dengan kepentingan keluarga dan masyarakat. Definisi ini menekankan bahwa kesejahteraan sosial adalah suatu institusi atau bidang kegiatan yang melibatkan aktivitas terorganisir yang diselenggarakan baik oleh lembaga-lembaga pemerintah maupun swasta yang bertujuan untuk mencegah, mengatasi atau memberikan kontribusi terhadap pemecahan masalah sosial, dan peningkatan kualitas hidup individu, kelompok dan masyarakat [9].

Masyarakat Madura di Pulau Madura sudah sangat lama diasosiasikan dengan atribut kemiskinan dan keterbelakangan (Wiyata dalam Andang, 2004). Atribut itu diperoleh karena kondisi alam Madura yang gersang dan tandus sehingga daya dukung alam, khususnya sektor pertanian, terhadap penduduk tidak memadai. Sebenarnya, sudah sejak zaman kolonial iptek dalam konteks industrialisasi memasuki Pulau Madura. Namun pada zaman itu, masih terbatas pada potensi Pulau Madura sebagai penghasil garam dan tembakau. Dengan potensi alam yang dimilikinya, industrialisasi merupakan alternatif terbaik bagi Madura untuk membangun kemakmuran. Pilihan ini cukup realistis bila dikaitkan dengan ekspansi industri yang berlangsung di Surabaya dan sekitarnya. Apa lagi dengan jembatan Suramadu yang mulai dibangun. Jembatan sepanjang 5.438 meter dan menelan dana sekitar Rp. 4,5 triliun tersebut merupakan jembatan terpanjang di Indonesia. Dengan jembatan tersebut "isolasi" Madura akan terbuka. Pulau Madura akan mudah diakses sehingga gagasan menjadikan Pulau Madura sebagai kawasan industri bukan hal yang mustahil.

Namun, kebijakan industri bukanlah pilihan yang mudah untuk dilaksanakan. Bukan karena infrastruktur untuk industrialisasi yang sama sekali belum tersedia di Madura, melainkan karena industrialisasi membawa konsekuensi perubahan sosial. Industrialisasi pada hakikatnya adalah penerapan iptek modern secara ekonomis dan hal ini, pada hakikatnya merupakan persoalan sosialisasi suatu kebudayaan yang terkait dengan aspek makro lainnya serta implikasi sosial. Banyak potensi ekonomi lokal yang bisa dikembangkan setelah Suramadu dioperasikan dan Madura menjadi daerah Industri. 
Secara administratif Pulau Madura dewasa ini juga dibagi menjadi empat wilayah kabupaten, yaitu Kabupaten Bangkalan, Kabupaten Sampang, Kabupaten Pamekasan dan Kabupaten Sumenep. Sejumlah hasil kerajinan warga seperti batik tulis dan gerabah yang kini mulai menguasai pasaran di lokal, nantinya akan lebih berkembang pesat. Demikian juga dengan kesenian tradisional dan makanan khas Madura.

Komoditi produk lokal di empat kabupaten di Madura sudah diincar pembeli lokal dan pedagang (tengkulak) di luar wilayah pulau Garam ini. Terbukti meningkat tajam nilai transaksi perdagangan pada pasar lelang selama dua periodik. Pasar lelang dijembatani Bakorwil IV Madura bekerjasama dengan Dinas Perdagangan dan Perindustrian Jatim, berlangsung di restroran Putri, mengundang sejumlah Pengusaha (Pedagang) dan para penjual terdiri dari UKM, kelompok Tani Se-Madura.

Mengingat peningkatan laju pertumbuhan ekonomi di Kabupaten Pamekasan khususnya di titik beratkan sektor pertanian dengan pengembangannya pada sektor industri yang dikaitkan dengan hasil pengolahan produksi dari pertanian, peternakan, dan perikanan menjadikan sektor industri juga mempunyai andil yang cukup besar dalam kegiatan ekonomi kabupaten Pamekasan. Industri kecil dan menengah yang tersebar sampai pelosok di Kabupaten Pamekasan dengan hasil produk yang cukup sukses dalam penjualan sebagai berikut: Batik tulis, teri nasi, ikan asin, petis, kripik tetteh, tahu tempe, anyaman dan aneka souvenir, kacang otto', rengginang, siwalan, garam dan perajangan tembakau.

Ekspor merupakan salah satu langkah utama yang ditempuh oleh pemerintah kabupaten Pamekasan untuk meningkatkan pendapatan (devisa) daerah. Berbagai cara mulai mencari terobosanterobosan baru sampai peningkatan kualitas \& kuantitas komoditi yang eksis-dilakukan untuk meningkatkan nilai dan volume ekspor. Berdasarkan jenis komoditi yang mempuyai volume dan nilai ekspor komoditi utama Kabupaten Pamekasan pada tahun 2007 antara lain cabe jamu dan tembakau yang menduduki pringkat teratas dengan volume berkisar 18174 ton, jika dihitung secara rupiah sekitar 545.220.000, hasil komoditi terbesar kedua adalah ikan,teri nasi dan rumput laut dengan volume 7512 ton, jika dihitung secara rupiah yaitu 112.680.000. sedangkan batik menduduki peringkat ketiga yakni dengan volume 250 kodi dengan harga rupiah yakni 37.500.000. garam sebagai hasil komuditi utama keempat dia mengeksport garam sebanyak 325 ton dengan penghasilan lumayan besar yaitu Rp.32.500.000. dan sapi potong menempati posisi terakhir yaitu 97.188 ekor dengan hasil Rp.3.401.580.000 [22].

Jauh sebelum batik di tetapkan sebagai warisan budaya dunia oleh United Nations Education, Scientific and Cultural Organization (UNESCO), pada 2 Oktober 2009 lalu, batik sudah tenar dan menjadi salah satu pengungkit perekonomin daerah. Entah karena latah atau tidak, yang pasti setelah UNESCO menetapkan batik sebagai warisan budaya dunia, geliat dunia perbatikan Indonesia termasuk Provinsi Jatim makin menggeliat. Di Jatim, geliat itu lebih terasa setelah Gubernur Jatim H Soekarwo pada November 2009 lalu, mewajibkan seluruh PNS di lingkungan Pemprov Jatim untuk memakai baju batik pada hari Kamis dan Jumat. Perusahaan swastapun juga ada yang mewajibkan karyawannya menggunakan pakaian batik pada harihari tertentu [23].

Selain itu, setiap daerah juga berlomba-lomba mencari dan membuat motif batik khas daerahnya. Termasuk Provinsi Jatim, yang menetapkan batik bermotif Ayam Bekisar dan Bunga Teratai sebagai motif batik khas Jatim. Ayam Bekisar dipilih karena fauna ini hanya ada di Jatim, khususnya di Pulau Sapeken Sumenep, dan Bunga Teratai merupakan simbol kedamaian sejak Kerajaan Singosari dan Kerajaan Majapahit. Tak hanya berhenti disitu, untuk melestarikan batik di Jatim, Gubernur Jatim H.Soekarwo juga menetapkan Kabupaten Pamekasan sebagai Kota Batik. Salah satu kabupaten di Pulau Madura ini memang layak ditetapkan sebagai Kota Batik pada 24 Juni 2009 lalu, bertepatan dengan peringatan Hari Bulan Gotong Royong Jatim di Pamekasan. Karena ketenaran batik Madura tidak bisa dilepaskan dari potensi batik yang ada di Kabupaten Pamekasan [23].

Ditetapkannya Kabupaten Pamekasan sebagai Kota Batik tidak secara kebetulan. Namun jauh sebelumnya, batik Pamekasan sudah mendapatkan pengakuan dari berbagai pihak, melalui prestasinya. Seperti Juara Pertama dalam pemasaran barang/sandang batik tulis di Festival Nusa Dua dan Expo Bali pada tahun 2007 dan 2008. Dalam Expo Indonesia Creative di Batam tahun 2009, pada kategori pemasaran barang kerajinan berbahan baku batik. Tak hanya itu, pada tahun yang sama juga menggondol juara satu dalam lomba pembuatan desain batik unik khas daerah yang diselenggarakan Dinas Kebudayaan dan Pariwisata Pemprov Jatim.

Berdasarkan latar belakang masalah di atas, maka rumusan masalah dalam penelitian ini adalah sebagai berikut:

1. Bagaimanakah peranan dinas perindustrian dan perdagangan dalam pemberdayaan batik sebagai budaya lokal di Kabupaten Pamekasan madura?

2. Bagaimanakah peranan pengrajin batik dalam pemberdayaan batik di Desa Klampar Kecamatan Proppo Kabupaten Pamekasan Madura?

3. Apa sajakah kendala-kendala yang dihadapi oleh Dinas Perindustrian dan Perdagangan dalam menjalankan peran untuk pemberdayaan pengrajin batik di Desa Klampar Kecamatan Proppo Kabupaten Pamekasan Madura?

\section{METODE PENELITIAN}

Metode penelitian yang digunakan dalam penelitian ini adalah metode kualitatif dengan pendekatan deskriptif. Tempat penelitian dilakukan di Dinas Perindustrian dan Perdagangan dan pengrajin 
batik di Desa Klampar Kecamatan Proppo Kabupaten Pamekasan Madura. Teknik pengumpulan data melalui wawancara, dokumentasi dan observasi.

Penetapan informan dilakukan melalui teknik purposive sampling. Informan kunci dalam penelitian ini adalah orang-orang yang diperkirakan mengetahui tentang proses dan hasil. Melalui data yang berupa dokumen diharapkan akan memperkuat hasil wawancara dengan informan terkait peranan Pemerintah Daerah dalam Pemberdayaan Budaya Lokal (studi pada Dinas Perindustrian dan Perdagangan dan Pengrajin Batik di Desa Klampar Kecamatan Proppo Kabupaten Pamekasan Madura).

Data dalam penelitian ini dianalisis dengan menggunakan teknik analisis data kualitatif model interaktif dari Miles dan Huberman (1992: 20), yaitu: 1) pengumpulan data; 2)Reduksi data; 3)Penyajian data; 4) Menarik kesimpulan.

\section{a. Pengumpulan Data}

Pengumpulan data merupakan kumpulan dari data-data informasi yang diperoleh dari hasil pengumpulan data, baik menggunakan observasi maupun wawancara. Proses analisis data dimulai dari menelaah seluruh data yang tersedia dari berbagai sumber, yaitu wawancara, observasi, dan dokumentasi. Data yang terkumpul masih berupa data mentah yang belum diolah sehingga perlu dipilah antara yang dianggap penting dan yang dianggap tidak penting.

b. Reduksi Data

Proses ini dimaksudkan untuk memperoleh datadata fokus dan lebih tajam, karena data yang menumpuk sulit memberikan gambaran yang jelas. Reduksi data merupakan proses pemilihan pemusatan perhatian pada penyederhanaan dan pengabstrahan dan transformasi data kasar yang muncul di lapangan. Data yang terkumpul akan direduksi sebagai upaya untuk mengorganisasikan data dalam memudahkan penarikan kesimpulan.

c. Penyajian Data

Data yang dihasilkan melalui proses reduksi data akan langsung disajikan sebagai sekumpulan informasi tersusun yang memberikan kemungkinan adanya penarikan kesimpulan dan pengambilan tindakan. Data disajikan secara tertulis berdasarkan kasus-kasus faktual yang saling berkaitan.

d. Menarik Kesimpulan/ Verifikasi

Menarik kesimpulan/ verifikasi yaitu proses mencari arti benda-benda, mencatat keteraturan, pola-pola penjelasan konfigurasi yang mungkin, alur sebab akibat dan proporsi peneliti. Kesimpulan juga diverifikasi selama penelitian berlangsung untuk mencari kesimpulan akhir.

\section{HASIL DAN PEMBAHASAN}

Dinas Perindustrian dan Perdagangan mempunyai struktur organisasi yang berfungsi untuk menjalankan tugas-tugas pemerintahan daerah dalam bidang perindustrian dan perdagangan. Struktur organisasi tersebut dikepalai oleh seorang kepala dinas dan dibantu oleh para anggota yang lain seperti sekretaris, sub bagian dan para kepala bidang beserta seksi-seksi yang membantu yang berjumlah sebanyak 4 bagian bidang yang langsung mendapat komando dari kepala dinas.

Program kerja Dinas Perindustrian dan Perdagangan Kabupaten Pamekasan dalam pemberdayaan pengrajin batik Pamekasan yaitu:

a. Permodalan melalui pinjaman Bank Perkreditan Rakyat (BPR)

Pemerintah Daerah bekerjasama dengan BPR jika ada para pengrajin maupun pengusaha batik ini melakukan pinjaman. Pinjaman sebesar Rp.2.000.000-Rp.3.000.000 tanpa bunga, sedangkan jika lebih dari itu akan dikenai bunga pinjaman.

b. Pelatihan membatik dan manajemen pemasaran Pelatihan biasanya diberikan kepada pengrajin batik untuk lebih membuat motif batik Pamekasan lebih berkualitas. Pelatihan ini memang tidak tentuk diberikan. Pelatihan batik ini tidak hanya diberikan kepada para pengrajinnya, tetapi juga para pengusaha batiknya untuk membenahi manajemen pemasaran dan lain-lain.

c. Pemunculan nuansa batik dalam setiap agenda acara yang ada ataupun menata kota dengan nuasa batik.

d. Mengikuti dalam berbagai agenda misalnya undangan KPRT di Kabupaten Bangkalan.

e. Membentuk paguyuban pengrajin batik yang di ketuai oleh bapak H. Ilzamuddin.

f. Pembuatan sentra batik di Pasar 17 Agustus yang dijadikan sentra ataupun pasar batik di Kabupaten Pamekasan yang merupakan gagasan dari mantan bupati Pamekasan yaitu Bapak Kholilurrahman.

g. Mencari solusi untuk meningkatkan eksistensi batik Pamekasan tidak hanya di Desa Klampar. Tetapi juga beberapa desa-desa lainnya yang ada di 7 Kecamatan penghasil batik dari 11 Kecamatan yang ada di Kabupaten Pamekasan. 7 Kecamatan diantaranya adalah:

a. Kecamatan Pamekasan 5 sentra yaitu Desa Kowel 2 sentra, Desa Toronan, Nyalabu Daja dan Kelurahan Gladak Anyar masing-masing 1 sentra.

b. Kecamatan Proppo 12 sentra yaitu Desa Klampar 5 sentra, Desa Toket dan Candi Burung masing-masing 3 sentra dan Desa Rang Perang Daja 1 sentra.

c. Kecamatan Palenggaan 6 sentra yaitu Desa Panyopelle 2 sentra, Desa Panaan, Desa Angsanah, Desa Akkor, dan Larangan Badung masing-masing 1 sentra.

d. Kecamatan Waru 1 sentra yaitu Desa Waru Barat.

e. Kecamatan Pegantenan 2 sentra yaitu Desa Bulangan Haji dan Desa Ambender.

f. Kecamatan Galis 1 sentra yaitu Desa Pagendingan. 
g. Kecamatan Tlanakan 1 sentra yaitu Desa Larangan Slampar.

Bentuk program pemberdayaan pengrajin batik tulis Kabupaten Pamekasan yang sudah dilakukan antara lain:

a. Tahun 2009: Peresmian Kabupaten Pamekasan sebagai Kabupaten Batik dengan adanya agenda pengadaan 1000 orang membatik dengan batik terpanjang di area arek lancor Kabupaten Pamekasan dan sempat memperoleh rekor MURI.

b. Tahun 2010: Setiap tahun mengikuti agenda semalam di Madura dan menggunakan batik tulis asli buatan pengrajin batik Kabupaten Pamekasan. Kabupaten Pamekasan pernah juga telah mewajibkan para pegawai dan para siswa-siswi untuk memakai batik pada hari-hari tertentu. Seperti pada hari kamis-jumat untuk para pegawai dan jumat-sabtu untuk para siswa-siswi di seluruh sekolah di Kabupaten Pamekasan.

c. Tahun 2011: juara 1-5 membatik tingkat Provinsi dan sekaligus sebagai juara umum yang diikuti oleh siswa dan umum dari Kabupaten Pamekasan.

d. Tahun 2012: tidak hanya pada tahun 2011, tetapi tahun 2012 Pamekasan juga menyabet juara umum membatik tingkat Provinsi yang diadakan oleh Dinas Perindustrian dan Perdagangan Provinsi Jawa Timur di Surabaya. Pembuatan sentra batik di Kabupaten Pamekasan yang diletakkan di pasar 17 Agustus. Tidak hanya itu saja, biasanya sering diadakan studi banding untuk meningkatkan inovasi motif batik yang ada di Kabupaten Pamekasan. Studi banding biasanya ke Solo dan Pekalongan bersama ibu-ibu PKK juga.

e. Tahun 2013: proses pembenahan dan penataan sentra batik di pasar 17 Agustus Kabupaten Pamekasan yang masih berlangsung dan mendirikan Desa Klampar sebagai sentra batik tulis di Pamekasan. Mengikuti banyak pameran juga telah dilakukan oleh Disperindag Kabupaten Pamekasan. Tidak hanya pameran, tetapi juga ada fashion show.

Selain bentuk program yang telah dilakukan oleh Dinas Perindustrian dan Perdagangan dalam hal pemberdayaan pengrajin batik Pamekasan, dinas juga memiliki program kerja yang sekarang sedang dilakukan antara lain:

1. Pembenahan sentra batik yaitu pasar 17 Agustus

2. Membuat master plan terkait persiapan Desa Klampar yang akan dijadikan sebagai pusat sentra batik di Kabupaten Pamekasan

3. Mengikuti pameran-pameran yang diadakan diluar Kabupaten Pamekasan seperti yang diadakan di Surabaya, Malang, Medan, Jakarta, Bangkalan dan daerah-daerah lainnya.

Membuat batik-batik yang ada diberbagai tempat pembuatan batik di Kabupaten Pamekasan bisa eksis seperti layaknya batik di Desa Klampar.

Dinas Perindustrian dan Perdagangan juga memiliki bentuk program pemberdayaan pengrajin batik Pamekasan yang akan dilakukan yaitu mengembangkan terus batik Pamekasan dengan cara sebagai berikut:

a. Meningkatkan kualitas dan kuantitas

b. Memberikan pelatihan kepada pengrajin dan pengusaha batik untuk membenahi proses pemasaran batik Pamekasan.

c. Seminar Kewirausahaan

d. Pembenahan bantuan dari sisi modal yang bekerjasama dengan Bank Perkreditan Rakyat (BPR) Pamekasan.

\section{Fungsi Alokasi}

Fungsi alokasi dapat dilihat dan dianalis dari ketersediaan sumber daya/ bahan baku dan sumber daya yang lain. bentuk bantuan penyediaan bahan baku dari pemerintah bisa dilihat pada bentuk program kerja Dinas Perindustrian dan Perdagangan Kabupaten Pamekasan dalam pemberdayaan pengrajin batik Desa Klampar Kecamatan Proppo Kabupaten Pamekasan yang sudah dilaksanakan, yang sedang dilaksanakan dan yang akan dilaksanakan yaitu sebagai berikut:

1. Membentuk paguyuban pengrajin batik yang di ketuai oleh bapak $H$. Ilzamuddin. Dengan dibentuknya paguyuban ini harapan pemerintah nantinya bisa meningkatkan eksistensi pengrajin dan pengusaha batik di Desa Klampar khususnya dan di Kabupaten Pamekasan pada umumnya, sehingga tidak lagi kekurangan sumberdaya/ bahan baku untuk pembuatan batik.

2. Peresmian Kabupaten Pamekasan sebagai Kabupaten Batik dengan adanya agenda pengadaan 1000 orang membatik dengan batik terpanjang di area arek lancor Kabupaten Pamekasan dan sempat memperoleh rekor MURI di tahun 2009 diharapkan bisa mendobrak potensi pengrajin batik di Kabupaten Pamekasan sebagai sumberdaya yang paling utama dalam proses pembuatan batik tulis.

Setelah dilakukan penelitian secara mendalam peneliti menemukan kendala yang dirasakan oleh pengrajin batik dalam mencari bahan baku yang alami seperti pewarna alami yang sejak dahulu dipergunakan untuk membuat batik tulis. Tidak adanya pewarna alami ini menyebabkan pengrajin batik tulis ini menggunakan pewarna buatan sebagai pengganti pewarna alami yang dibiasanya didapat dari tumbuhtumbuhan.

Untuk ketersediaan bahan baku yang paling utama seperti kain (mori) yang biasanya dipergunakan oleh pengrajin batik biasanya dibeli di toko kain dalam partai besar, jika dihitung permeternya bisa seharga Rp. 15.000, sedangkan kain batik madura biasanya menggunakan 2 meter kain, jadi bisa ditotal Rp. 30.000 untuk 1 lembar batik yang akan dijual dipasaran. Sebenarnya bermacam-macam harga kain (mori) yang dapat dipergunakan.

\section{Fungsi Distribusi}

Fungsi distribusi bisa dianalisis dari adanya bantuan permodalan dari pemerintah serta bantuan 
pemasaran dari pemerintah dalam rangka pemberdayaan batik Pamekasan. Hal tersebut bisa dilihat pada bentuk program kerja Dinas Perindustrian dan Perdagangan Kabupaten Pamekasan dalam pemberdayaan pengrajin batik Desa Klampar Kecamatan Proppo Kabupaten Pamekasan yang sudah dilaksanakan, yang sedang dilaksanakan dan yang akan dilaksanakan yaitu sebagai berikut:

1. Permodalan melalui pinjaman Bank Perkreditan Rakyat (BPR) Pemerintah Daerah bekerjasama dengan BPR jika ada para pengrajin maupun pengusaha batik ini melakukan pinjaman. Pinjaman sebesar Rp.2.000.000-Rp.3.000.000 tanpa bunga, sedangkan jika lebih dari itu akan dikenai bunga pinjaman.

2. Mencari solusi untuk meningkatkan eksistensi batik Pamekasan tidak hanya di Desa Klampar. Tetapi juga beberapa desa-desa lainnya yang ada di 7 Kecamatan penghasil batik dari 11 Kecamatan yang ada di Kabupaten Pamekasan.

3. Di tahun 2010 hingga saat ini, setiap tahun mengikuti agenda semalam di Madura dan menggunakan batik tulis asli buatan pengrajin batik Kabupaten Pamekasan. Kabupaten Pamekasan pernah juga telah mewajibkan para pegawai dan para siswa-siswi untuk memakai batik pada hari-hari tertentu. Seperti pada hari kamis-jumat untuk para pegawai dan jumatsabtu untuk para siswa-siswi di seluruh sekolah di Kabupaten Pamekasan.

4. Mengikuti pameran-pameran yang diadakan diluar Kabupaten Pamekasan seperti yang diadakan di Surabaya, Malang, Medan, Jakarta, Bangkalan dan daerah-daerah lainnya.

Dengan adanya penelitian ini maka bisa disimpulkan bahwa dari fungsi distribusi peranan Pemerintah Daerah yang dalam hal ini Dinas Perindustrian dan Perdagangan hanya mengandalkan pinjaman tanpa bunga sebesar Rp.2.000.000Rp.3.000.000 dari Bank Perkreditan Rakyat (BPR) serta Dinas Perindustrian dan Perdagangan Kabupaten pamekasan banyak mengikuti pameran-pameran yang diadakan diluar Kabupaten Pamekasan. Hal ini dilakukan dalam rangka membuka link. Tetapi hal ini tidak cukup membantu para pengrajin dan pengusaha batik di Desa Klampar pada khususnya dan para pengrajin dan pengusaha batik di Kabupaten Pamekasan pada umumnya karena dirasa modal itu terlalu kecil untuk dijadikan modal usaha. Sedangkan untuk pendistribuasian dari hasil batik dari Kabupaten Pamekasan ini hanya menggunakan link bukan dari Pemerintah. Para pengrajin dan pengusaha batik ratarata menjual atau mendistribusikan batiknya dengan cara dijual dipasar atau gallery yang dimiliki, dikirimkan kepada saudara yang bekerja di Luar Negeri serta penjualan melalui media sosial.

\section{Fungsi Stabilitas}

Fungsi Stabilitas bisa diamati dari adanya Pelatihan keterampilan yang intensif dan penyediaan lokasi distribusi di area lokal kabupaten Pamekasan, nasional maupun internasional untuk batik Kabupaten Pamekasan. Hal tersebut bisa dilihat pada bentuk program kerja Dinas Perindustrian dan Perdagangan Kabupaten Pamekasan dalam pemberdayaan pengrajin batik Desa Klampar Kecamatan Proppo Kabupaten Pamekasan yang sudah dilaksanakan, yang sedang dilaksanakan dan yang akan dilaksanakan yaitu sebagai berikut:

1. Pelatihan membatik dan manajemen pemasaran. Pelatihan biasanya diberikan kepada pengrajin batik untuk lebih membuat motif batik Pamekasan lebih berkualitas. Pelatihan ini memang tidak tentuk diberikan. Pelatihan batik ini tidak hanya diberikan kepada para pengrajinnya, tetapi juga para pengusaha batiknya untuk membenahi manajemen pemasaran dan lain-lain.

2. Membentuk paguyuban pengrajin batik yang di ketuai oleh bapak $\mathrm{H}$. Ilzamuddin.

3. Pembuatan sentra batik di Pasar 17 Agustus yang dijadikan sentra ataupun pasar batik di Kabupaten Pamekasan yang merupakan gagasan dari mantan bupati Pamekasan yaitu Bapak Kholilurrahman.

4. Membuat master plan terkait persiapan Desa Klampar yang akan dijadikan sebagai pusat sentra batik di Kabupaten Pamekasan.

Pelatihan membatik dan manajemen pemasaran sering saja diikuti oleh para pengrajin batik seperti yang diadakan oleh Dinas Perindustrian dan Perdagangan Provinsi Jawa Timur. Untuk paguyuban ini dibentuk dalam rangka membuat ikatan emosional antara para pengrajin dan pengusaha batik, serta membuat pemerintah tidak susah untuk memberikan bantuan. Pembuatan sentra batik yang diletakan di pasar 17 Agustus membuat sedikit para pengrajin dan sekaligus pengusaha batik mendapatkan tempat untuk menjual batik hasil karyanya. Sedangkan untuk pusat sentra batik yang rencanya akan diletakkan di Desa Klampar Kecamatan Proppo Kabupaten Pamekasan ini masih dalam tahap perencanaan.

Ketiga fungsi yang telah dijabarkan ini telah menunjukkan program kerja Pemerintah Daerah yang dalam hal ini adalah Dinas Perindustrian dan Perdagangan dalam rangka proses pemberdayaan batik Desa Klampar Kecamatan Proppo Kabupaten Pamekasan Madura. Meninjau kembali indikator pemberdayaan, seperti meningkatkan kesadaran dan keinginan untuk berubah kepada pengrajin batik melalui seminar kewirausahaan serta adanya pelabelan bahwa Pamekasan dijadikan kabupaten batik. Kedua, meningkatkan kemampuan individu untuk berubah dan meningkatkan kesempatan untuk memperoleh akses yang dilakukan pemerintah dengan cara mengikutkan batik-batik pamekasan dan para pengrajinnya serta pengusahanya dalam acara pameran-pameran di berbagai daerah, tetapi hal ini dirasa oleh para pengrajin dan pengusaha batik masih kurang maksimal. Ketiga, perubahan pada hambatanhambatan sumber dan kekuasaan pada tingkat rumah tangga, masyarakat dan makro; kekuasaan atau 
tindakan individu untuk menghadapi hambatanhambatan tersebut dalam hal ini Dinas Perindustrian dan Perdagangan masih kurang memberikan perhatian kepada para pengrajin maupun para pengusaha batik di Desa Klampar pada khususnya dan Kabupaten Pamekasan pada umumnya terkait bantuan dana ataupun bantuan bahan baku, serta tidak adanya kontrol pemerintah langsung kepada pengrajin batik terkait dengan keseimbangan pendapatan dengan proses produksi, hanya saja pemerintah sedikit membuat akses pasar yang diletakkan di pasar 17 agustus yang dijadikan pasar batik. Keempat, meningkatkan solidaritas atau tindakan bersama dengan orang lain untuk menghadapi hambatanhambatan sumber dan kekuasaan pada tingkat rumah tangga, masyarakat dan makro, hal ini diwujudkan oleh pemerintah dengan cara membentuk asosiasi pengrajin batik Se-kabupaten Pamekasan.

\section{Pemberdayaan Pengrajin Batik Desa Klampar Kecamatan Proppo Kabupaten Pamekasan Madura}

Secara konseptual, pemberdayaan atau pemberkuasaan (empowerment), berasal dari kata "power" (Kekuasaan atau keberdayaan). Karenanya ide utama pemberdayaan bersentuhan dengan konsep mengenai kekuasaan. Kekuasaan sering kali dikaitkan dengan kemampuan kita untuk membuat orang lain melakukan apa yang kita inginkan, terlepas dari keinginan dan minat mereka.

\section{a. Sejarah berdirinya batik Klampar}

Menurut buku The Heritage of Indonesia Pamekasan Membatik edisi ke-2 karangan mantan Wakil Bupati Pamekasan yakni Kadarisma Sastrodiwiryo (2012) yang bukunya memang belum beredar secara luas dipasaran dijelaskan bahwa pada tahun 1873 Van Rijekevorsel seorang saudagar Belanda, menyerahkan ke Museum etnik di Rotterdam selembar batik yang diperolehnya ketika berkunjung ke Indonesia. Perjalanan sejarah batik berkait erat dengan kerajaan Majapahit dan penyebaran Islam di Jawa.

Batik Madura sebagaimana di Jawa, menggunakan bahan kain mori dan bukan tenun, kendatipun tenun juga dikenal pada masa lalu. Dulu di Madura ada "Tenun Poleng" yang berasal dari nama tokoh legenda Ki Poleng. Tokoh ini mengawal Raden Segoro, yang dipercaya sebagai leluhur orang Madura. Tenun poleng ini, sekarang sudah tidak ditemui lagi.

Mengiringi kebangkitan Batik Tanjung Bumi, batik di tiga Kabupaten lainnya juga bangkit. Di Sampang batik tulis berkembang dengan baik. Batik Sampang memiliki pola tersendiri yang menjadi ciri khasnya. Demikian halnya di Sumenep, batik tulis juga berkembang yang kemudian berpusat di Desa Pekandangan, Kecamatan Prenduan yang memperoleh binaan dari Pemkab Sumenep.

Di Pamekasan, batik menemukan lahan yang subur, dan berkembang hampir diseluruh wilayah Kabupaten. Batik menjadi komoditas andalan bahkan menjadi icon industri kecil. Sejak itu, utamanya pada tahun-tahun terakhir ini, terjadi pergeseran pusat batik Madura. Kalau dulu berada di Bangkalan, sekarang bergeser ke Pamekasan.

Batik Desa Klampar merupakan salah satu industri batik di Kabupaten Pamekasan Madura yang masih bertahan sampai saat ini, batik Desa Klampar didirikan sebagai usaha untuk melestarikan budaya dan melanjutkan warisan nenek moyang. Batik Madura dikenal sejak zaman kerajaan Majapahit. Hal ini dibuktikan dengan relief dan patung yang menggunakan batik sebagai pakian kebesaran kerajaan. Arya Wiraraja sebagai adipati Sumenep pertama adalah pembantu Raden Wijaya yang mengenalkan batik pada masyarakat Madura. Di Pamekasan, batik mulai dikenal masyarakat luas setelah terjadi perang antara kyai penghulu Bagandan (Raden Azhar) dengan Ke' Lesap pada tahun 1700 Masehi. Waktu itu Kyai Penghulu menggunakan batik dengan motif parang (leres: Bahasa madura).

Kyai Penghulu Bagandan Pamekasan menikah dengan Nyai Qadhi yang bersaudara dengan Nyai Kammalah (Nyai Toronan) yang masih berdarah Giri Kedaton. Dari pernikahan ini dikaruniai cicit Kyai Taman Toronan yang berdomisili di Desa Toronan Pamekasan. Kyai Taman berputra Kyai Mudari yang berdomisili di Dusun Banyumas Desa Klampar Kecamatan Proppo Kabupaten Pamekasan Madura. Cucu inilah yang melestarikan batik sebagai pakaian kebangsawanan Madura yang dikenal hingga saat ini sebagai batik asli buatan Dusun Banyumas Desa Klampar Kecamatan pamekasan Madura.

Sebagai bentuk aspirasi peninggalan sejarah, Bapak H. Ilzamuddin AMd, keturunan Kyai Penghulu Bagandan (Raden Azhar) ke-9 bersama dengan para pembatik di Dusun Banyumas lainnya berinisiatif membangun sentra batik yang lebih representatif, modern dan mudah dijangkau oleh seluruh pencinta batik nusantara dan internasional. Maka pada tahun 2010 sentra batik inipun terealisir dengan sebutan Kampoeng Batik Pamekasan.

H. Ilzamuddin ini merintis awal usahanya pada tahun 1999 dengan modal usaha Rp.750.000. dengan modal inilah akhirnya bisa berkembang dengan dibukanya galeri batik di desa Klampar Kecamatan Proppo Kabupaten Pamekasan Madura pada tahun 2010. Hal tersebut berdasarkan wawancara yang dilakukan peneliti dengan Bapak H. Ilzamuddin sebagai pemilik galeri batik "Mutiara Pamekasan" di Desa Klampar.

\section{Alat dan bahan pembuatan batik di Desa Klampar}

Batik di Desa Klampar Kecamatan Proppo Kabupaten Pamekasan Madura ini memiliki dua jenis produk batik, yaitu batik tulis dan batik cap.Adapun alat dan bahan yang dibutuhkan dalam pembuatan keempat jenis produk batik asli buatan Desa Klampar antara lain :

1. Batik Tulis

Alat dan bahan yang dipergunakan dalam proses pembuatan batik Tulis antara lain:

a. Dingklik/ tempat duduk 


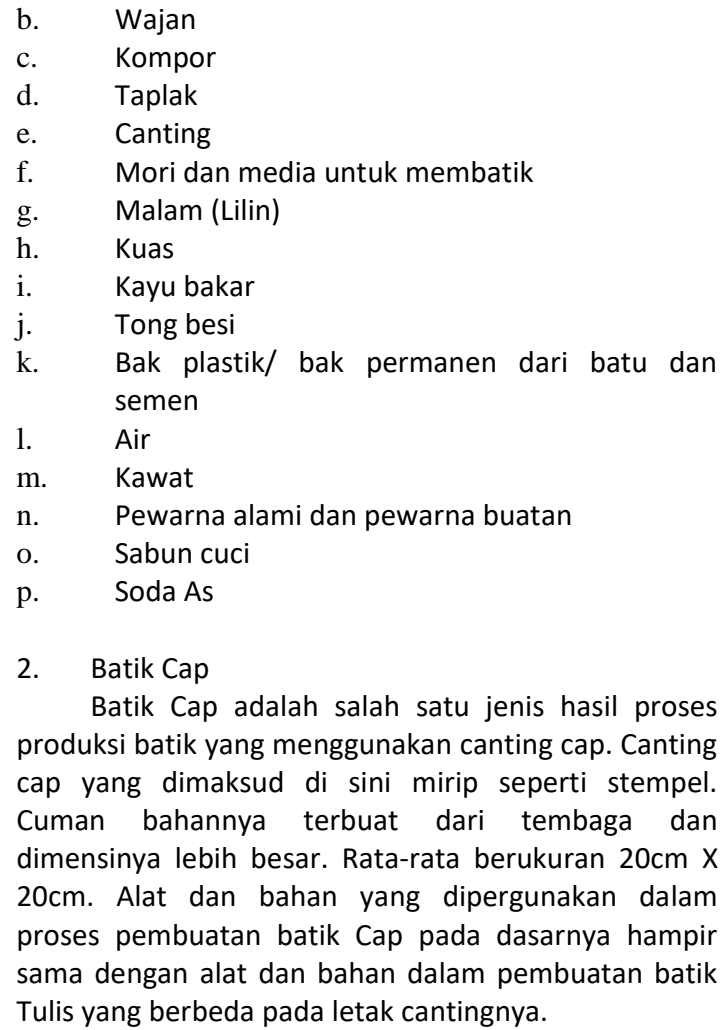

Proses pembuatan batik Desa Klampar Kecamatan Proppo Kabupaten Pamekasan.

Secara umum proses pembuatan batik melalui 4 tahapan yaitu pewarnaan, pemberian malam (lilin) pada kain, pelepasan lilin dari kain dan pengeringan.

\section{Proses pembuatan batik tulis}

Tahap awal adalah dengan mempersiapkan medianya yaitu kain mori dengan melalui beberapa langkah yaitu:

a. Pemotongan kain mori

b. Pencucian kain mori

c. Mengetel

d. Menganji

e. Mengemplong

f. Menggambar Pola

g. Pembatikan

h. Pencolekan

i. Pemberian malam

j. Pencelupan pertama

k. Menghilangkan Malam ke-1

I. Penggunaan malam ke 2

m. Pencelupan ke 2

n. Menghilangkan malam ke-2

o. Pencelupan ke 3

p. Menghilangkan malam ke-3

q. Penjemuran batik

\section{Proses pembuatan batik Cap}

Tidak seperti batik tulis yang proses pembuatannya menggunakan canting, pada proses pembuatan batik cap alat yang digunakan yaitu cap (semacam stempel besar yang terbuat dari tembaga) yang sudah didesain dengan motif tertentu dengan dimensi $20 \mathrm{~cm} \times 20 \mathrm{~cm}$.

\section{Motif batik Desa Klampar Kecamatan Proppo Kabupaten Pamekasan Madura}

Batik Pamekasan tidak berbeda jauh dengan batik dari daerah lainnya yang membedakan adalah motif, serta kekuatan warna yang merupakan ciri khas dari daerah tersebut. Beberapa motif yang paling banyak dibuat di Pamekasan antara lain "Sekarjagad","Beras Tumpah", "mata keteran","Pecah Batu", serta "Serat Kayu". Keempat motif tersebut merupakan satu di antara berbagai motif yang dimiliki para perajin Batik di Pamekasan.

Diantara batik pesisiran, batik Madura memiliki ciri khas, yaitu,

1. Motifnya jelas, tegas, ekspresif dan naturalis biasanya bertema lingkungan hidup.

2. Pelukisan tanpa menggunakan mal, pola atau patron

3. Kepekatan warna kuat, sehingga tidak mudah luntur. Bahkan ada batik yang disebut Bhatek Genthongan, warnanya tahan lama karena waktu perendaman cukup lama dengan teknik dimasukkan dalam gentong.

Jenis batik di kabupaten Pamekasan sangatlah beragam. Ada 43 motif batik yang bisa kita lihat di pasaran. Dari 43 motif batik tersebut bisa kita pecah menjadi 2 jenis batik yaitu jenis batik tradisional/klasik dan jenis batik modern. Jenis batik tradisional atau klasik diantaranya adalah motif batik beras tumpah, sekarjagad, mata keteran, bulan kenari, be rebbe, fajar menyingsing, gunung sempai, kenari, junjung drajat, kar pote, rek lancor, deng bendeng ramok, kembang gadung, leres kembang, kerapan sapi, kismis, kokleko, ker teker, leng kelleng, pi kopi, lidi halus, lo polo, okel kembang, beng geddung, ramok leres/dengbendeng, rang kerrang, carcenah, sessek, wa' duwa', cong pecong, tong centong, bulu ajem, sabet manik, po'onan/buketan, tumpal leres, kerrang buah muris, belling pecca. Sedangkan untuk batik jenis modern ada 5 motif baru di pasaran batik Kabupaten Pamekasan yaitu batik motif serat kayu, pecah batu, abstrak, pagisore dan tiga dimensi.

\section{Pemasaran batik Pamekasan}

Berdasarkan pernyataan dari pemilik batik Pamekasan diatas, bentuk-bentuk pemasaran batik Pamekasan selama ini antara lain :

1. Galeri Batik

2. Peran masyarakat

3. Peran media massa

4. Peran pemerintah daerah 
Kendala-kendala yang dihadapi dan upaya-upaya yang dilakukan oleh Dinas Perindustrian dan Perdagangan dalam menjalankan peran untuk pemberdayaan pengrajin batik di Desa Klampar Kecamatan Proppo Kabupaten Pamekasan Madura.

Upaya Dinas Perindustrian dan Perdagangan selama ini dalam pemberdayaan pengrajin batik Pamekasan pada umumnya banyak menemui kendala. Kendala-kendala yang dihadapi oleh Dinas Perindustrian dan Perdagangan dalam pemberdayaan terhadap pengrajin batik Pamekasan adalah sebagai berikut:

a. Sumber daya manusia yang terlibat dalam usaha industri kecil masih rendah utamanya di bidang kewirausahaan batik

b. Proses daya saing pasar yang masih kurang

c. Kualitas yang masih kalah saing dengan batik Pekalongan dan Yogyakarta

Dengan banyaknya kendala yang dihadapi, maka dirasa perlu mencari upaya-upaya untuk menghadapi kendala-kendala yang ada dalam pemberdayaan batik. Upaya-upaya itu antara lain adalah sebagai berikut:

1. Pembenahan pada sisi Sumber Daya Manusia dengan cara pelatihan-pelatihan untuk meningkatkan kreativitas para pengrajin batik. sumber daya manusia inilah yang akan menjadi hal yang paling mendasar, karena batik tulis adalah hasil karya tangan secara langsung yang dibuat oleh manusia. Sehingga diharapkan kualitasnya juga cukup baik.

2. Dengan adanya penyediaan pasar 17 agustus sebagai pasar batik di Kabupaten Pamekasan diharapkan bisa menjadi lebih efektif untuk para pengusaha batik untuk tidak menyewa toko. Tidak hanya itu saja tetapi proses pengemasan saat penjualan itu juga menjadi hal yang penting. Meskipun dijualnya dipasar, harapannya pengemasannya juga bisa sedikit elegan.

3. Motif batik pamekasan ini berbeda dengan motifmotif batik di daerah lain. Tidak hanya motif, warnanyapun sangat menyolok yang berbeda dengan daerah-daerah lainnya. Sehingga diharapkan Dinas Perindustrian dan Perdagangan Kabupaten Pamekasan Madura nanti bisa mendatangkan ahli seni untuk memberikan pelatihan terkait motif batik dan pewarnaan agar motif dan pewarnaan batik Pamekasan bisa mengalami perkembangan.

\section{PEMBAHASAN}

Peranan Dinas Perindustrian dan Perdagangan dalam pemberdayaan batik sebagai budaya lokal di Kabupaten Pamekasan Madura

Peranan Dinas Perindustrian dan Perdagangan dalam hal ini mencakup 3 hal yakni fungsi alokasi, fungsi distribusi dan fungsi stabilitas. Menurut hasil penelitian dilapangan dapat di ketahui bahwa fungsi alokasi yang di maksud adalah kurang ketersediaannya bahan baku seperti bahan pewarna alami serta kain (mori) yang biasanya dipergunakan untuk sebagai bahan utama dalam membuat batik. responden yang telah diwawancarai mengatakan, jarang sekali bantuan dari pemerintah terkait bahan baku kain (mori). Jika dibeli dipasaran, kain putih ini (mori) biasanya seharga Rp.15.000/meter dan biasanya setiap 1 lembar kain batik Pamekasan ini menghabiskan 2-3 meter/potong. Sehingga bisa diperkirakan, jika 1 potong kain mori seharga Rp.30.000. dengan harga seperti itu para pengrajin baik hanya mendapatkan kainnya saja, belum mendapatkan bahan-bahan lainnya. Sedangkan jika dilihat dipasaran, batik Pamekasan relatif sangat murah yakni berkisar Rp.60.000-100.000. meskipun terkadang ada juga yang mahal karena proses pembatikannya yang relatif susah dan lama, serta kainnya juga. hal ini sangat tidak sesuai dengan tenaga yang dipergunakan untuk membatik, mewarnai, memberikan malam dan menghilangkan malam dengan air mendidih.

Ditinjau dari fungsi distribusi, bantuan permodalan dari Pemerintah dirasa masih kurang oleh para pengrajin maupun pengusaha batik. Bantuan modal itu tidak tentu bisa dirasakan oleh para pengrajin batik. Sehingga para pengrajin dan pengusaha batik mencari solusi untuk mendapatkan modal dengan meminjam di koperasi dan menggunakan dana pribadi meskipun dirasa sangat sedikit. Untuk proses distribusi, tidak hanya bantuan modal saja yang diharapkan oleh para pengrajin dan pengusaha batik, tetapi bantuan jaringan informasi dalam rangka proses pemasaran batik juga sangat diperlukan. Sampai saat ini pula pemerintah hanya sebagai fasilitator informasi adanya pameran. Sehingga diharapkan, dari adanya pameran itu para pengrajin dan pengusaha batik ini bisa mendapatkan link untuk lebih memperlebar sayap dalam rangka penjualan/ distribusi batik tulis Pamekasan. Proses pemasaran batik madura juga sampai ke berbagai daerah lainnya seperti Surabaya, Malang, Jakarta, Bandung dan Yogyakarta hingga sampai juga di beberapa Negara tetangga seperti Singapura, Malaysia dan Arab Saudi berdasarkan link dari saudara dan teman. Pameranpameran diberbagai daerah juga terkadang diikuti oleh para pengrajin dan pengusaha batik Pamekasan seperti di Surabaya, Yogyakarta dan Jakarta. Terkadang Dinas Perindustrian dan Pedagangan juga mengikuti pameran tersebut, seperti yang diadakan di Pekanbaru dalam jangka waktu 1 tahun ini.

Fungsi stabilitas akan dipergunakan pemerintah dalam rangka meningkatkan kualitas dan kuantitas batik Pamekasan. Peningkatan kualitas ini seperti misalnya proses peluruhan malam agar lebih sempurna, serta proses inovasi motif batik tulis asli Kabupaten Pamekasan. Untuk itu Pemerintah Daerah Kabupaten Pamekasan melalui Dinas Perindustrian dan Perdagangan mencoba bekerjasama dengan Dnas Perindustrian Provinsi Jawa Timur untuk mengadakan pelatihan membatik dan pelatihan kewirausahaan untuk lebih meningkatkan kualitas. Tidak hanya kualitas yang diharapkan bisa mendobrak pasar batik nasional, tetapi kuantitas inilah juga harapannya bisa dipikirkan oleh para pengrajin dan Dinas Perindustrian 
dan Perdagangan Kabupaten Pamekasan karena hal ini berkaitan dengan permintaan pasar. Penyediaan lokasi sentra batik di Kabupaten Pamekasan dirasa sangat diperlukan, untuk itu pada tahun 2012 Pemerintah Kabupaten Pamekasan melalui Dinas Perindustrian dan Perdagangan Kabupaten Pamekasan membuka sentra batik yang berlokasi di pasar 17 agustus. Disinilah para pengrajin dan sekaligus pengusaha batik asal Desa Klampar dan beberapa Desa lainnya dari Kabupaten Pamekasan berkumpul untuk menjual batik hasil buatan tangannya. tetapi pasar tradisional ini yang juga menjual hasil laut dan berbagai hasil bumi dirasa kurang efektif karena sedikit jauh dari pusat kota dan terkadang membuat para wisatawan asing susah untuk singgah ke pasar tersebut. Apalagi jika mengingat, pasar 17 agustus tersebut hanya bisa ramai pengunjung jika hari-hari tertentu seperti hari kamis dan minggu. Ada juga gallery batik milih Pemerintah Daerah Kabupaten Pamekasan yang terletak dipusat kota yang berdampingan dengan Perpustakaan Umum Kota Pamekasan. Tetapi jika dibandingkan, harga batik di pasar 17 agustus dengan batik yang ada di gallery itu sangat jauh berbeda, jauh lebih mahal di gallery. Jika ditijau dari hasil penelitian ini, yang cenderung dirugikan adalah para pengrajin batiknya yang biasanya menjual batik dengan harga relatif sangat murah. Tidak hanya galleri yang dibuka oleh Pemerintah Daerah Kabupaten Pamekasan tetapi ada juga gallery yang dibuka atas nama perorangan. Seperti gallery batik Sorayya dan Latansa yang namanya sudah cukup terkenal di Kabupaten Pamekasan.

\section{Peranan pengrajin batik dalam pemberdayaan batik Pamekasan}

Peranan pengrajin batik di Desa Klampar Kecamatan Proppo Kabupaten Pamekasan jika ditinjau dari sisi proses pembuatannya pengrajin batik sangat berusaha memenuhi kualitas dan kuantitas batik di Kabupaten Pamekasan. Dari sisi kualitas, pengrajin batik masih menekankan pada motif dan corak warna yang khas serta proses-proses membatik yang dilakukan secara sederhana. Proses pembuatan batik tulis, sebenarnya tidak jauh berbeda dengan batik cap, perbedaannya hanya terletak pada penulisan atau pengecapan kain saja. Selebihnya semuanya sama. Tidak hanya motif lama yang dipergunakan, tetapi motif-motif baru yang diinovasi dengan motif lama juga mulai dibuat sesuai dengan permintaan pasar. Selain motif, pewarnaan juga cukup berpengaruh, para pemuda-pemudi biasanya tidak ingin menggunakan corak warna terang, sehingga dibuatlah warna-warna soft untuk memenuhi permintaan tersebut. Sehingga, 2 tahun yang lalu salah 1 warna soft ini bisa memenangkan lomba membatik tingkat SMA yang diadakan oleh Dinas Perindustrian dan Perdagangan Provinsi jawa Timur.

Proses pemasaran batik juga tidak jauh dari peran pengrajin batik dan pengusaha batik di Kabupaten Pamekasan. Dengan adanya pasar 17 agustus yang didirikan oleh Dinas Perindustrian dan
Perdagangan maka para pengrajin dan pengusaha batik bisa memasarkan atau mendistribusikan batik hasil buatannya untuk dijual. Selain pasar 17 agustus sebagai pasar batik, Desa Klampar Kecamatan Proppo Kabupaten Pamekasan juga sudah dideklarasikan sebagai sentra batik di Kabupaten Pamekasan. Untuk itu, Pemerintah masih akan membuat master plan untuk lebih memfokuskan perencanaan tersebut. Seperti lokasi, jalan dan parkir di daerah tersebut nantinya. Di Desa terserbut sudah nampak gallerygallery batik yang cukup terkenal dan mempunyai nama yang berangkat atas nama dana atau modal perorangan/sendiri. Sehingga pemerintah bisa segera merealisasikannnya dan bekerjasama dengan pemerintah terkait, seperti masalah jalan yang bisa dikoordinasikan dengan dinas perhubungan.

Kendala-kendala yang dihadapi oleh Dinas Perindustrian dan Perdagangan dalam pemberdayaan batik Pamekasan.

Kendala-kendala yang dihadapi oleh Dinas Perindustrian dan Perdagangan dalam pemberdayaan terhadap pengrajin batik Pamekasan secara internal adalah sebagai berikut:

a. Sumber daya manusia yang terlibat dalam usaha industri kecil masih rendah utamanya di bidang kewirausahaan batik.

b. Kualitas yang masih kalah saing dengan batik Pekalongan dan Jogyakarta

Kendala-kendala yang dihadapi oleh Dinas Perindustrian dan Perdagangan dalam pemberdayaan terhadap pengrajin batik Pamekasan secara eksternal adalah Proses daya saing pasar yang masih kurang, tidak seperti batik Pekalongan dan Solo yang sudah mempunyai nama (brand) sehingga mudah untuk menembus pasaran nasional. Batik Pamekasan dirasa masih belum bisa menembus pasar nasional maupun internasional karena batik Pamekasan kurang bisa menjaga kualitas batik tulisnya, seperti halnya dalam pencopotan malam yang dirasa kurang maksimal, sehingga para konsumen merasa batik yang akan dibeli sangat kasar.

Dengan banyaknya kendala yang dihadapi, maka dirasa perlu mencari upaya-upaya untuk menghadapi kendala-kendala yang ada dalam pemberdayaan batik. Upaya-upaya secara internal yang akan dilakukan antara lain adalah sebagai berikut:

1. Pembenahan pada sisi Sumber Daya Manusia dengan cara pelatihan-pelatihan untuk meningkatkan kreativitas para pengrajin batik. sumber daya manusia inilah yang akan menjadi hal yang paling mendasar, karena batik tulis adalah hasil karya tangan secara langsung yang dibuat oleh manusia. Sehingga diharapkan kualitasnya juga cukup baik.

2. Dengan adanya penyediaan pasar 17 agustus sebagai pasar batik di Kabupaten Pamekasan diharapkan bisa menjadi lebih efektif untuk para pengusaha batik untuk tidak menyewa toko. Tidak hanya itu saja tetapi proses pengemasan saat penjualan itu juga menjadi hal yang penting. 
Meskipun dijualnya dipasar, harapannya pengemasannya juga bisa sedikit elegan.

Tidak hanya upaya-upaya secara internal yang akan dilakukan tetapi upaya secara ekternal juga akan dilakukan antara lain, motif batik pamekasan ini berbeda dengan motif-motif batik di daerah lain. Tidak hanya motif, warnanyapun sangat menyolok yang berbeda dengan daerah-daerah lainnya. Sehingga diharapkan Dinas Perindustrian dan Perdagangan Kabupaten Pamekasan Madura nanti bisa mendatangkan ahli seni untuk memberikan pelatihan terkait motif batik dan pewarnaan agar motif dan pewarnaan batik Pamekasan bisa mengalami perkembangan serta dibutuhkan studi banding lanjutan untuk meningkatkan kualitas batik di Kabupaten Pamekasan Madura.

\section{KESIMPULAN}

Berdasarkan paparan data di atas dan temuan penelitian, maka kesimpulan dalam penelitian ini adalah sebagai berikut:

1. Kegiatan yang dilakukan oleh pemerintah dirasa kurang mampu meningkatkan pemberdayaan pengrajin batik Pamekasan jika ditinjau dari 3 fungsi, yaitu fungsi alokasi, distribusi dan fungsi stabilitas.

2. Bentuk program pemberdayaan pengrajin batik Pamekasan yang dilaksanakan oleh Dinas Perindustrian dan Perdagangan dilakukan dalam bentuk program kerja yang sudah, sedang, dan akan dilakukan. Kendala-kendala Dinas Perindustrian dan Perdagangan dalam pemberdayaan pengrajin batik Baronggung antara lain sumber daya manusia yang terlibat dalam usaha industri kecil masih rendah utamanya di bidang kewirausahaan, terbatasnya kemampuan dalam mengakses pasar, rendahnya minat generasi muda dalam bidang batik, kurangnya kreativitas yang stagnasi produk yang disebabkan oleh faktor usia pengusaha yang relatif sudah tua dan faktor minimnya pengetahuan tentang disain batik, permodalan, lemahnya teknologi yang dipergunakan dan belum adanya aturan yang bersifat mengikat terkait batik di Kabupaten pamekasan. Hanya saja peneliti dapat menemukan visi dan misi kabupaten pamekasan yang memang sejalan dengan visi dan misi Pengembangan Ekonomi Kreatif tahun 2025.

3. Peranan pemerintah daerah yang dalam hal ini adalah Peranan Dinas Perindustrian dan Perdagangan berkaitan erat dengan pemberdayaan menurut teori dari Suharto (2010: 58-59) yaitu pemberdayaan bertujuan untuk meningkatkan kekuasaan orang-orang yang lemah atau tidak beruntung. Sehingga hal ini yang menjadi arah pemerintah untuk pemberdayaan budaya lokal yang ada yang dalam hal ini adalah batik yang merupakan hasil karya seni dari masyarakat. Peranan dari pemerintah dalam pemberdayan batik masih kurang maksimal karena pemerintah kurang bisa menciptakan suasana atau iklim yang memungkinkan potensi masyarakat untuk berkembang yang berkaitan erat dengan lokasi, alat dan bahan pembuatan batik, yang kedua adalah memperkuat potensi dan daya yang dimiliki masyarakat yang harapannya bisa meningkatkan kualitas dan kuantitas batik sehingga bisa meningkatkan pendapatan asli daerah, yang ketiga adalah memberdayakan dengan cara melindungi yaitu tidak adanya aturan hukum yang jelas terkait batik di Kabupaten Pamekasan.

4. Upaya yang dilakukan oleh Dinas Perindustrian dan Perdagangan dalam mengatasi kendalakendala dalam pemberdayaan pengrajin batik yaitu memberikan pelatihan, ikut serta dalam pameran dan studi banding ke daerah-daerah lain, meningkatkan kualitas sumber daya manusia baik kepada pengrajin sendiri maupun pembinannya, memunculkan kreasi baru kerajinan batik dengan corak maupun warna, membentuk asosiasi pengrajin batik, mengenalkan seni membatik kepada generasi muda, memberikan kemudahan dalam kredit usaha bagi semua perusahaan batik, dan menumbuhkan kecintaan terhadap produksi lokal kepada generasi muda terutama batik.

\section{SARAN}

Diharapkan pengrajin batik di Desa Klampar pada khususnya dan kepada seluruh pengrajin batik di Kabupaten Pamekasan pada umumnya, agar mampu meningkatkan daya kreatifitasnya dalam membuat hasil karya batik sehingga bisa terus berkarya untuk melestarikan budaya lokal Kabupaten Pamekasan dengan selalu bekerjasama dengan Dinas Perindustrian dan Perdagangan dalam pemberdayaan pengrajin batik.

Pemerintah daerah dalam hal ini Dinas Perindustrian dan Perdagangan Kabupaten Pamekasan, membantu para pengrajin batik dalam hal pemberian pelatihan secara rutin, bantuan bahanbahan baku, bantuan permodalan dan bantuan distribusi dan infomasi kepada konsumen.

Selain itu masyarakat, agar lebih mencintai produk dalam negeri dan produk daerahnya masingmasing terutama batik. Sebagai generasi muda yang baik, seharusnya bisa menjaga budaya yang dimiliki serta jangan menganggap bahwa batik itu kuno atau ketinggalan zaman. Batik juga bisa mengikuti perkembangan zaman.

Untuk mahasiswa ilmu administrasi publik, agar melakukan penelitian lebih lanjut tentang pemberdayaan pengrajin batik karena masih banyak lagi pemberdayaan-pemberdayaan pengrajin tidak hanya pengrajin batik yang ada di daerah lain yang belum diteliti. 


\section{UCAPAN TERIMA KASIH}

Alhamdulilah, berkat segenap rahmat dan pertolongan Allah SWT serta dukungan dari berbagai pihak, penulis dapat menyelesaikan jurnal ini. Untuk itu, penulis menyampaikan ucapan terima kasih yang sebesar-besarnya kepada: Prof. Dr. Yuli Andy Gani, selaku Komisi Pembimbing dan Dr. Hermawan M.Si selaku anggota Komisi Pembimbing, yang telah meluangkan waktu dan memberikan bimbingan, ilmu, wawasan, inspirasi, serta motivasi dalam penulisan tesis ini. Dan Kepala Dinas Perindustrian dan Perdagangan dan Seluruh staf di Dinas Perindustrian dan Perdagangan atas kesempatan yang diberikan kepada penulis untuk melaksanakan penelitian ditempat tersebut sebagai syarat untuk menyelesaikan pendidikan Strata-2.

\section{DAFTAR PUSTAKA}

[1]. Bungin, Burhan. 2003. Analisa Data penelitian Kualitatif. Pemahaman Filosofis dan Metodologis ke Arah Penguasaan Model Aplikasi. Jakarta: PT Raja Grafindo Persada.

[2]. Kartasasmita, Ginanjar. 1996. Pembangunan Untuk Rakyat: Memadukan Pertumbuhan dan Pemerataan. CIDES: Jakarta.

[3]. Koentjaraningrat. 1990. Kebudayaan Mentalitas dan Pembangunan. PT Gramedia Pustaka Utama: Jakarta.

[4]. Kuntjara, Esther. 2006. Penelitian Kebudayaan (Sebuah Panduan Praktis). Graha Ilmu: Yogyakarta.

[5]. Mayang, Nita,dkk. 2011. Geographic Information System (GIS) Untuk Keanekaragaman Budaya Indonesia. Program Studi Manajemen Informatika: Bandung.

[6]. Moeljono, Djokosantoso. 2005. Budaya Organisasi Dalam Tantangan. PT Alex Media Komputindo: Jakarta.

[7]. Moleong, L.J. 2000. Metode Penelitian Kualitatif. PT Remaja Rosda Karya: Bandung.
[8]. Soelaeman, Munandar. 2007. IImu Budaya Dasar (Suatu Pengantar). PT Refika Aditama: Bandung.

[9]. Suharto, Edi Ph.D. 2010. Membangun Masyarakat Memberdayakan Rakyat. PT Refika Aditama: Bandung. Oparinde, Suleiman Sunkanmi. 2012. Batik As a Cultural Identity of The YORUBA: Hand Colouring Technigues and Applications, Possibility of Adaptation. MA Graduate: Nigeria.

[10]. Abidinsyah. 2003. Pemberdayaan Ekonomi Rakyat masyarakat Pesisir di Kota Tarakan Propinsi Kalimantan Timur (Kajian Pelaksanaan Pemberdayaan Ekonomi Masyarakat Pesisir di Kelurahan Mamburung Kecamatan tarakan Timur). Tesis. PPSUB. Malang.

[11]. Bachranie, Ahmad. 2003. Model Pemberdayaan Masyarakat Melalui Pengembangan Industri Kecil di Desa Panyiuran Kecamatan Muantai Selatan Kabupaten Hulu Sungai Utara Propinsi Kalimantan Selatan. Tesis. PPSUB. Malang.

[12]. Fauzan, Mohammad. 2007. Etnobotani Tumbuhan Bahan Pewarna Alami Batik Banyu Mas di Kabupaten pamekasan. Skripsi. UIN Malang.

[13]. Gemayana, Iswan. 2005. Strategi Pemerintah Kabupaten Sukamara Dalam Pemberdayaan Ekonomi Masyarakat (Studi Tentang Pemberdayaan Usaha Kecil Pembuatan Krupuk Ikan di Kecamatan Sukamara Kabupaten Sukamara Propinsi Kalimantan Tengah). Tesis. PPSUB. Malang.

[14]. Hanafiyah, E.M. 2004. Pemberdayaan Masyarakat Melalui Program Gerbang Dayaku dalam Rangka Mengentaskan Kemiskinan. Tesis PPSUB. Malang.

[15]. ,,,. 2008. Agenda 21 for culture. Institut de cultura: Barcelona.

[16]. ,',' . 2004. Agenda 21 for culture. Institut de Cultura: Ajuntament de Barselona.

[17]. Dinas Perindustrian dan Perdagangan kabupaten pamekasan Madura tahun 2007.

[18]. Media Online Bhirawa: 2012 